\title{
The Head Posture of Alexander the Great
}

\begin{abstract}
Some portraits show Alexander the Great with his neck twisted and head tilted, mostly to the left, occasionally to the right. Similarly, Plutarch and later sources describe Alexander as having a tilted or twisted neck. This head posture has been subject to discussion by archaeologists as well as physicians. While most archaeologists believe the posture to be a question of iconography, many physicians have put it down to a physical defect. In fact, in very recent medical publications, Alexander is still presented as suffering from torticollis, twisted neck, a diagnosis launched in the mid-nineteenth century. This study concludes that a potential physical defect is unlikely to have been depicted in the official portraits of Alexander.
\end{abstract}

"Every schoolboy knows that Alexander's head was inclined slightly towards the left shoulder"

Alfred Emerson 1886.

The portraiture of Alexander the Great (356-322 BC) follows a readily recognizable formula that includes a number of characteristic traits such as a full head of hair, upswept over the forehead in an anastole, a cloudy brow, large deep-set eyes, full and slightly parted lips, a strong chin and sturdy neck. These features are not necessarily all present in a single portrait; the leitmotif is the anastole, whereas the length and fullness of the hair vary. Alexander's head posture also varies. In some portraits the head is held straight, eyes looking right ahead. Other portraits show a slight head turn, mostly to the left, while still other images display a twist of the neck and a tilted head. Within the large corpus of Alexander and Alexander-like images there is thus considerable divergence. ${ }^{1}$

With the possible exception of a youthful head in the Acropolis museum (FIG. 1), taken by some as an original work by Leochares, but probably of Roman date, all extant large-scale

\footnotetext{
1. The most comprehensive study of Alexander's portraiture is Stewart 1993. Colour photos in, e.g., Yalouris 1980; Alfano 1995; Moreno, 2004a; Pandermalis 2004. The numerous discussions of Alexander's portraiture include: Gebauer 1938-39; Bieber 1964; Hölscher 1971; Schwarzenberg 1976; Hartle 1982; Pollitt 1986, 20-31; Kiilerich 1988; Ridgway 1990, 108-48; Tonsing 2002; Stewart 2003; Wünsche 2006; Hölscher 2009; von den Hoff 2009; von den Hoff 2014 (with ten page bibliography).
} 


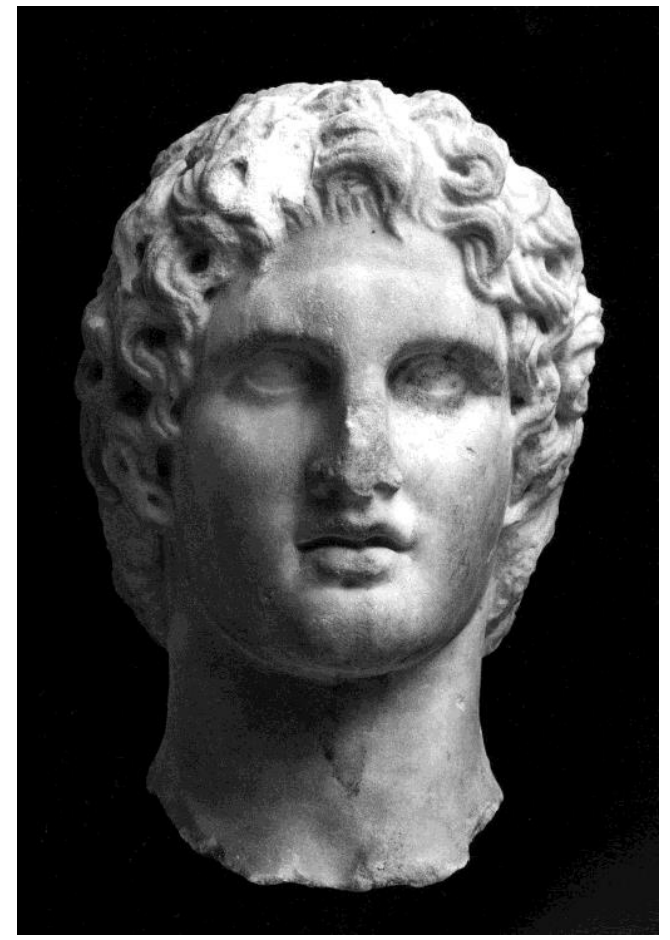

FIG. 1 - Alexander. Ca 330 BC or later. Athens, New Acropolis Museum, inv. no. 1331 (photo: museum).

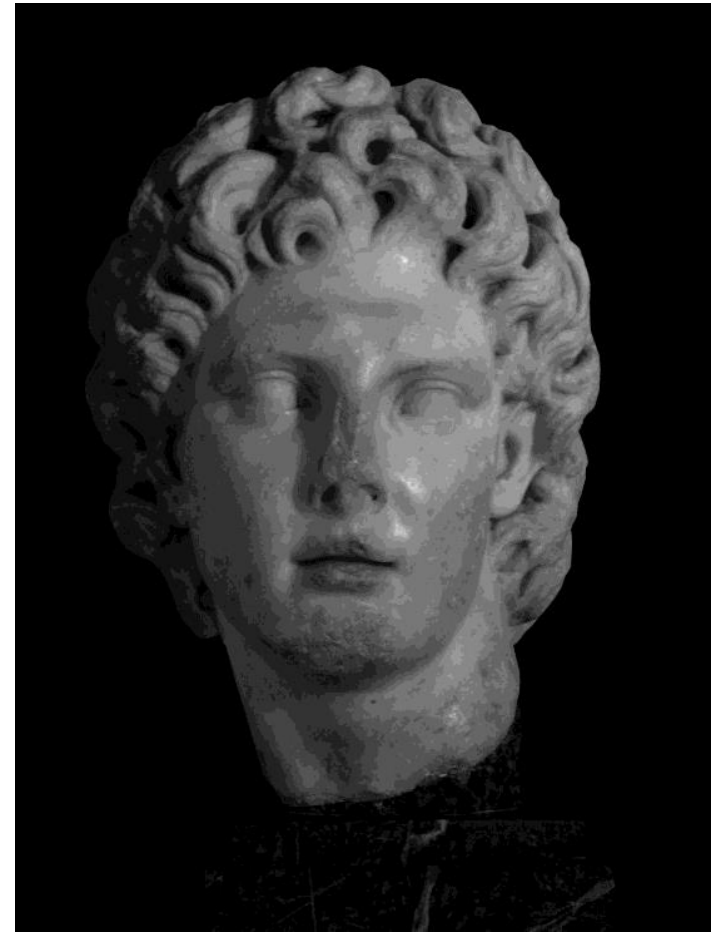

FIG. 2 - Alexander/Apollo from Italica (Santiponce). Roman. Seville, Archaeological Museum (photo: author).

representations of Alexander are likely to be posthumous. ${ }^{2}$ It is often difficult to ascertain whether a given head derives from a portrait made in Alexander's lifetime or whether the variant was created centuries later. Moreover, many of the portraits believed to represent the king have no secure provenance, their original context being totally uncertain. Furthermore, most heads were part of whole figures, and with the body missing, important information has been lost. It is therefore hardly surprising that the dating and interpretation of individual works can be subject to strong disagreement. ${ }^{3}$

Over the years the 'Alexander look' was reformulated by different artists at different times and places. The popular image was also used for other characters, including divinities and heroes. This has resulted in a profusion of Alexander-like images and ensuing uncertainty as to which of these were actually meant to portray Alexander himself. Examples include an Alexander/Apollo from Italica (FIG. 2), an Alexander in Catania and a late antique Alexander/Meleager in Milan. ${ }^{4}$ To complicate matters, post-antique Nachbildungen and downright fakes have entered the large corpus of Alexander images and partly clouded our perception of the original portrayals of the king.

\footnotetext{
2. Athens, New Acropolis Museum, Akr. 1331; Stewart 1993, 106-10, 421, fig. 5; Alfano 1995, 209; Pandermalis 2004, 18-19.

${ }^{3 .}$ For the various approaches and methodological problems, see Stewart 1993, 56-70.

4. Fernández Gomez n.d, 133; Cagiano de Azevedo 1967.
} 
When surveying extant Alexander portraits that display a strong asymmetry, either in the form of a wry neck or marked upward or outward gaze, it must be noted that some heads with exaggerated features are of either dubious authenticity (for instance, the Boston head and the Fortnum head in Oxford have been challenged) or reformulated post-antique renderings (e.g., some dying Alexanders in marble and porphyry). ${ }^{5}$ Consequently, although these various images reflect ideas of how to represent a ruler in the 'heroic' tradition of the youthful Alexander, most of these images probably bear only slight resemblance to the no-longer-extant portraits made during the ruler's lifetime.

\section{The visual evidence of turned and tilted heads}

A point of departure for studying the portraiture of Alexander the Great has been the inscribed Azara herm in the Louvre. This weathered and restored work of the second century $\mathrm{AD}$, found at Tivoli, has often been associated with Lysippos and especially with his bronze statue of Alexander with the lance. ${ }^{6}$ In spite of its wretched state of conservation, it furnishes some visual clues, preserving as it does some recurrent features of Alexander's iconography: the anastole and the full but comparatively lanky hair. Alexander is presented with his head held straight and, except for an ever-so-slight turn to the right, an almost frontally poised head as required by the herm format. Nonetheless, it was an examination of this herm, which led A. Dechambre to diagnose Alexander with torticollis (see below p. 8 and FIG. 6).

Other images depict Alexander with a turned and sometimes tilted head. These representations range from a slight, via a medium to a strong turn, and the degree of tilt or inclination also ranges from slight to strong. Because the variations are gradual, strict classification is neither possible nor desirable. Owing to the difficulty of dating Alexander's portraits, it is also ill-advised to search for a chronology with regard to different degrees of inclination. The large Pergamon Alexander has a slight inclination to the left (FIG. 3). ${ }^{7}$ A head in Copenhagen, one of many extant images said to come from Alexandria, has a vigorous left turn of the head (FIG. 4). ${ }^{8}$ A pronounced inclination is shown in a marble from Yannitsa near Pella. ${ }^{9}$ Plausibly dating from the third century BC, it is one of the earliest images preserved (unless of course the Acropolis Alexander is a fourth-century original). This head displays a marked inclination to the left with the central line of the face slanting to form a sharp angle to the neck (FIG. 5a). The sculpture is broken off through the neck, and the intended poise is uncertain. A portrait from Volantsa on the Peloponnese, perhaps from the later third century, displays a similar bent. ${ }^{10}$ Both heads are above life size. Variations on the twisted pose are found in portraits

\footnotetext{
${ }^{5 .}$ Boston, Museum of Fine Arts, 95.68; Stewart 1993, 333-34, 424, fig. 131. Fortnum head: Stähli 2000. Schwarzenberg 1969 with pls. 63-68, presents many examples of post-antique works.

6. Paris, Louvre, MA 436; Johnson 1927, 215, mentions a dozen early publications where this attribution was already made; Stewart 1993, 161-71, 423, fig. 45-46.

7. Istanbul, Archaeological Museum, inv. 1138; Stewart 1993, 332-33, 430, fig. 128-29. Radt 1981, unconvincingly argues that the head stems from the Pergamon altar. Anti: Wünsche 2006.

${ }^{8 .}$ Copenhagen, Ny Carlsberg Glyptotek, inv. 574; Johansen 1992, 66-67; Stewart 1993, 251, 424, fig. 84; Moreno 1995, 162-63.

9. Pella Archaeological Museum, GL 15; Stewart 1993, 284-86, 430-31, fig. 97; Pandermalis 2004, 20-21.

10. Olympia museum, L 245; Stewart 1993, 332, 430, fig. 127.
} 


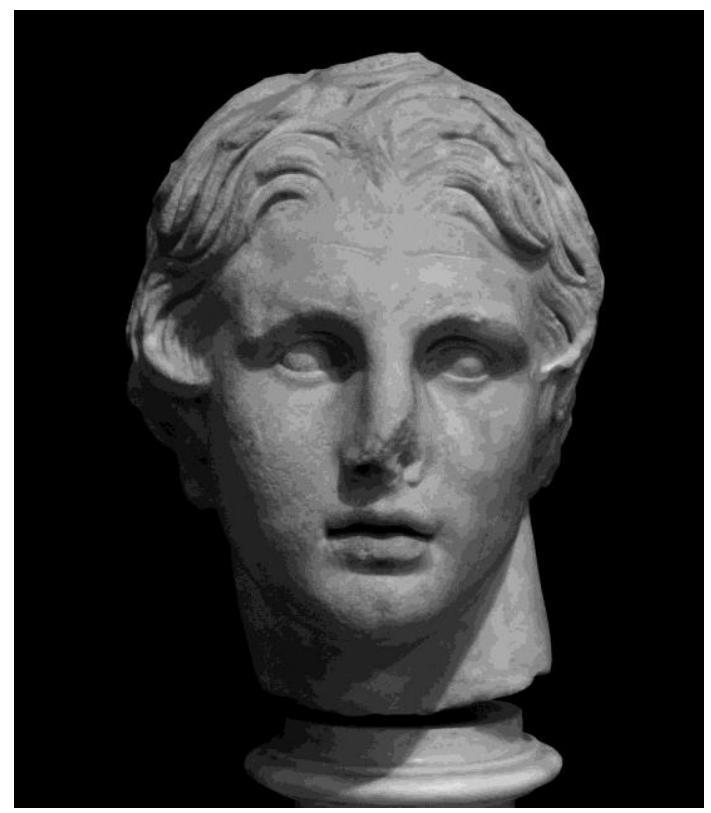

FIG. 3 - Alexander from Pergamon. Ca 175-150 BC. Istanbul Archaeological Museum, inv.no. 1138 (photo: author).

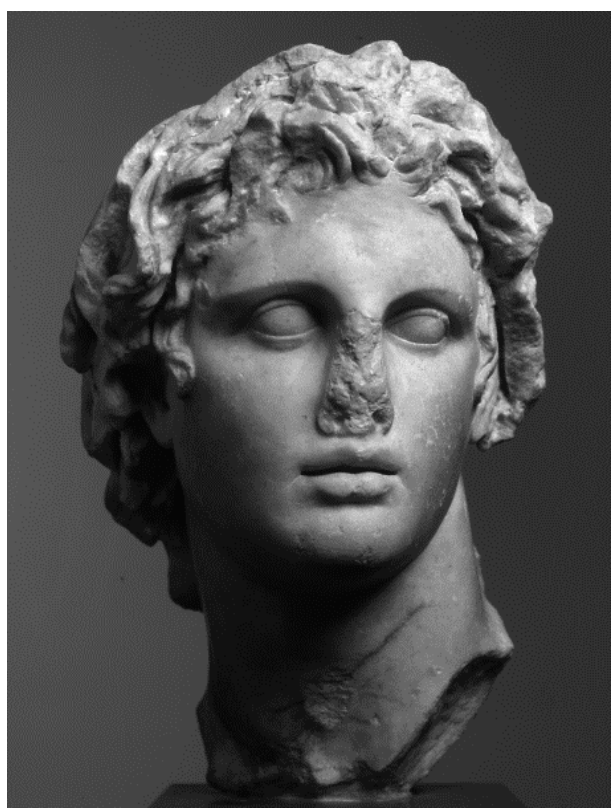

FIG. 4 - Alexander, allegedly from Alexandria. Third century BC. Copenhagen, Ny Carlsberg Glyptotek, inv.no. 574 (photo: Mauseum).
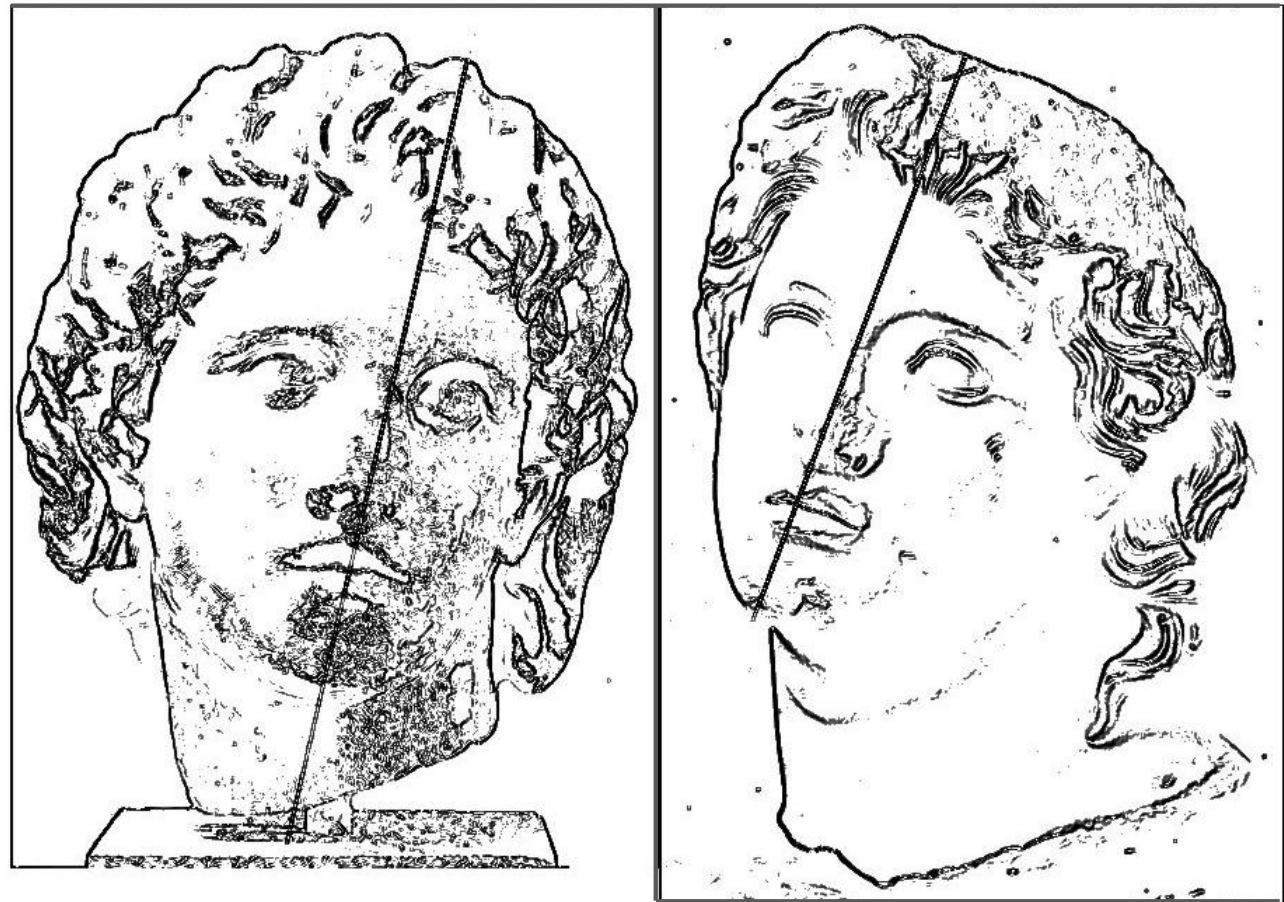

FIG. 5a - Alexander from Yannitsa, Macedonia. Third century BC. Pella, Archaeological Museum, GL. 15. 5b. Alexander from Ptolemais Hermiou, Roman period. Boston, Museum of Fine Arts, no. 95.98 (sketches: author). 
with an upward turn and gaze, as, for instance, a gilded bronze in Rome with a slight upward poise combined with a turn to the right. ${ }^{11}$ The heavenward gaze is also rendered in profile images on coins, as for instance in Lysimachos' minting of Alexander with ram's horns, ca. $300 .{ }^{12}$ A particularly strong tilt is seen in the more romanticized versions, such as the Alexander-Helios in Rome and Boston. ${ }^{13}$ The colossal Boston marble has an especially marked inclination (FIG. 5b). Said to stem from Egypt, but fashioned from Carrara marble, the suspicion of it being a nineteenth-century fake cannot quite be laid to rest. In any case it may be significant that in these images the head tilt is combined with a luxurious mass of hair.

On the tiny ivory heads from Vergina Tomb II, ca 336 (if the man buried there is Philip II) or ca 317 (if he is Philip III), the no-longer-extant hair was probably made of a different material and plausibly gilded, the reliefs being miniatures in the chryselephantine technique. Although hardly actual portraits they should be mentioned for their possible reflection of official ruler images of the day. The one identified as 'Alexander' has an undeniably twisted neck and upward-turned head. ${ }^{14}$

Regrettably these various marble and ivory images are merely fragments whose original appearance and contexts are difficult to reconstruct. For a complete figure, the bronze statuette known as the Fouquet Alexander may give a very rough idea of Lysippos' famous Alexander with the lance. It displays a head turn to the right. ${ }^{15}$ Thus among preserved images in various media, a turned or tilted head is a recurrent feature. Alexander's head posture was also subject to comments by ancient writers.

\section{The literary sources}

A number of comparatively late textual sources refer to Alexander the Great as having a crooked or tilted neck. ${ }^{16}$ The earliest and most important of these is Plutarch, who addresses Alexander's physical appearance in the Parallel Lives (Life of Alexander) and in the Moralia (On the Fortune and Virtues of Alexander the Great). Most other texts are considerably later and derive from a long tradition handed down through the centuries. Plutarch, who wrote some four hundred years after Alexander's death, drew on many different accounts bolstered by the evidence of statues. ${ }^{17}$ His description is thus a secondary or tertiary interpretation of

\footnotetext{
11. Rome, Museo Nazionale, Palazzo Massimo, inv. 66177; Alfano 1995, 273, no. 63. Other candidates than Alexander are certainly possible.

12. Lysimachos' tetradrachm: Stewart 1993, fig. 117. For the numismatic evidence in general: Price 1991; Dahmen 2007.

13. Rome, Museo Capitolino, Stewart 1993, 333-34, 424; Moreno 1995, 401; Boston, Museum of Fine Arts, 95.68; Stewart 1993, 333-34, 424, fig. 131.

14. Andronikos 1988, 122-33 with large-scale colour photos, 'Alexander' figs. 76-78. Full page colour photos in, e.g., Yalouris 1980, pl. 34. The identity of the king buried in Royal tomb II where the ivory heads were found is still hotly debated. Based on studies of the skeletal material, Musgrave 2010 and Antikas \& Wynn-Antikas 2015 argue for Philip II (the latter suggesting that the woman buried in the antechamber is not his sixth wife Eurydike, but his seventh wife or concubine, a Scythian princess). Bartsiokas, most recently in 2015, argues for Philip III Arrhidaios in Tomb II and Philip II in Tomb I. For an overview of some of the problems of identifying the deceased and dating the artefacts, see Chilidis 2012, 57-64.

15. Yalouris 1980, no. 41; Stewart 1993, 163-171.

16. The ancient sources on Alexander's appearance: Johnson 1927, 298-307; Moreno 1973 with comments and discussion; Stewart 1993, 341-50 (texts T 1-27); for the neck: T 8-11; T 21; T 24-27.

17. Enoch Powell 1939 points to twenty-four different sources; Cook 2001 estimates an even higher number.
} 
literary and visual sources. ${ }^{18}$ In the Moralia, Plutarch describes Lysippos' first portrait of Alexander 'as gazing upwards (ano bleponta) with his face towards the sky, as he used to gaze with a slight inclination of the neck' (hesyche parengklinon ton trachelon). The Greek historian further informs us that Lysippos was the only one who succeeded in rendering Alexander's ethos and arête in bronze. Aiming to imitate his upward neck turn (ten apostrophe tou trachelou) and moist eyes, the other artists failed to preserve his virility and leonine character. ${ }^{19}$ Addressing the visual images again in his biography of Alexander, Plutarch stresses that the king's physical appearance is best seen in Lysippos' statues. He further notes that Lysippos rendered most faithfully the features which many of Alexander's friends and followers tried to imitate, such as the inclination of the neck bent lightly to the left (ten anatasin tou auchenos eis euonumon hesyche keklimenou). ${ }^{20}$ Here it may be asked whether Plutarch had actually seen Lysippos' statue of Alexander with the lance, copies of this or other statues in the Lysippic tradition, or whether he based his account solely on earlier writers' description. $^{21}$

Plutarch, in other passages, mentions the flexure of the neck (engklisin tou trachelou) as a feature worth imitating. ${ }^{22}$ Pyrrhos, king of Epeiros (295-272 BC), is singled out for having imitated Alexander's bending of the neck (klisei trachelou). ${ }^{23}$ According to Themistios, in the fourth century $\mathrm{AD}$, the satraps mimicked Alexander's poise (ton auchena epi ton euonumon omon). ${ }^{24}$ Caracalla is reported to have displayed (in effigy) a neck tilted towards the left shoulder (ad laevum humerum conversa cervice), a peculiarity he is said to have noticed in Alexander's corpse when paying a visit to his tomb. ${ }^{25}$ Mainly repeating the information provided by Plutarch, the Byzantine writer Ioannes Tzetzes (born ca 1110 in Constantinople) addresses Lysippos' statues of Alexander in three texts. He designates the posture with three terms, heterotrachelon (with the neck turned to one or the opposite side), paratrachelon (with the neck on one side) and simotrachelon (with the neck turned upward). The words heterotrachelon and paratrachelon are used twice. ${ }^{26}$

Noticeable in the various texts is the lack of a common term for the poise of the neck. It is variously described as klisis, engklisis and parengklisis; the head is keklimenon in Plutarch, while the Byzantine Tzetzes, for the sake of elegant variation, refers to the neck as heterotrachelon, paratrachelon and simotrachelon. Other words used in connection with an upward gaze are apostrophe, roughly indicating twisting or turning away and anatasis, straining. ${ }^{27} \mathrm{It}$ can also be referred to as cervice celsa, a lofty neck. ${ }^{28}$ A variant term is therefore used in each

\footnotetext{
18. Cf. L'Orange 1947, 22: 'the representation in art, not the actual person of Alexander underlies the description'; Wardman 1967. Leimbach 1979, takes the neck as a characteristic of the real Alexander.

19. Plutarch, De Alexandri Magni fortuna aut virtute 2. 2, Moralia 335A-B; Johnson 1927, 305; Stewart 1993, 343 , T 9.

20. Plutarch, Alex. 4.1; Johnson 1927, 304-05; Stewart 1993, 344, T 10.

Müller 2014.

22. Plutarch, Moralia 53 D (ca 80 AD); Stewart 1993, 343, T 8.

23. Plutarch, Pyrrhos 8.1 (ca 110 AD); Stewart 1993, 345, T 11.

24. Themistios, Logoi politikoi 13 (year 364 AD), Stewart 1993, 349, T 24.

25. Anon., Epitome de Caesaribus Sexti Aureli Victoris 21.4 (fourth c. AD), Stewart 1993, 348, T 21.

26. Tzetzes, Epistulae 76 (heterotrachelon), Chiliades 8.200,421 (paratrachelon), 11.368.97: (heterotrachelon, simotrachelon, paratrachelon); Stewart 1993, 349-50, T 25-27.

27. Respectively, De Alex. 2.2, and Alex. 4.2.

28. Solinus, Collectanea rerum memorabilium 9.20 (ca AD 260), Stewart 1993, 346, T 17.
} 
reference: in some, the head or neck is said to be tilted down, in others it is tilted to the side, in still others it is raised.

In addition to the head posture, the sources provide information on the alleged physical appearance of Alexander. He is reported to have been less impressive than his friend Hephaisteion, who on one occasion was mistaken for Alexander. It is also inferred that he was of comparatively short stature: when he sat down on King Dareios' throne, his feet did not reach the footstool. ${ }^{29}$ As for his countenance, he is presented as having fair skin (leukos could also indicate a shining complexion), which tended to redden (epiphoinissen) in the face and the chest. ${ }^{30}$

Another distinct feature was Alexander's lack of beard growth. This grooming style soon came into fashion and became the chosen paradigm for heroic ruler representation in the Hellenistic period. ${ }^{31}$ The fact that Alexander acceded to the throne at the age of 22, still a very young man, makes it reasonable to assume that he then was either beardless or merely sported a youthful, sparse growth of beard. When once his public image had been designed in accordance with ideas of quasi-divine eternal youthfulness, it was only natural to retain the beardless look. ${ }^{32}$ Perhaps to indicate that Alexander had reached the age of a light beard growth, some images depict him with sideburns: they can be seen on the Alexander mosaic from Pompeii, ca $100 \mathrm{BC}$, and on later artworks such as the gold medallion from Aboukir, ca AD 230, and on a sculpted tondo from Aphrodisias, ca AD $425 .^{33}$ The presence of sideburns in works of such different date and geographical provenance indicates that this is a reasonably stable feature - if not of the real Alexander, at least of his portraiture.

Several late sources mention the peculiarity of iris heterochromia, eyes of different colour (heterochromia iridum or binocular heterochromia, as opposed to heterochromia iridis, uniocular or sectorial, with areas of the same iris in different colours). According to PseudoCallisthenes, Alexander's 'right eye was heavy-lidded and black/dark blue (kuanoblefaron) and the left one was blue' (glaukos: of pale colour, blue, possibly including shades of green and grey). ${ }^{34}$ Julius Valerius renders 'quasi nigra glauca atque coeli similis', almost black and sky-blue. ${ }^{35}$ Tzetzes similarly notes that Alexander was said to have different-coloured eyes (heterophthalmos), blue and black (glaukon and melana). ${ }^{36}$ This alleged peculiarity has been interpreted by some physicians as a symptom of a congenital or acquired disorder, and several publications of heterochromia of the iris mention Alexander as an early sufferer. ${ }^{37}$

\footnotetext{
29. Diodorus Bibl. 17.37.5 (ca 50 BC); Diod. 17.66.3; Curtius 5.2. 13-15; Drews 1962; Stewart 1993, 341-42, T 2-3.

30. Plutarch, Alex. 4.3.

31. Athenaios, Deipnosophistai 13, 565a, A (230 BC); Stewart 1993, 341, T 1.

32. For image-building and Alexander, see Kiilerich 1993. For the youthful image of Alexander, see Hölscher 2009, who points to the revolutionary nature of this new ruler image.

33. For the mosaic, see Andreae 1977; Cohen 1997; Moreno 2000; Ehrhardt 2008. For the medallion: e.g., Pandermalis 2004, 33 no. 12. For the tondo: Smith 1990, 135-38, pl. 8, 9. 1-3; Kiilerich 1993, 90, fig. 6. For Alexander's images in late antiquity, see Kiilerich 2015, 23-24.

34. Ps.-Callisthenes, Bios Alexandrou 1.13.3 (ca AD 300); Brown 1949; Stewart 1993, 346, T 18.

35. Jul. Valerius, Res Gestae Alexandri 1.7 (fourth c. AD); Stewart 1993, 347, T 19.

36. Tzetzes, Chiliades 11, 368, 97; Stewart 1993, 350, T 27.

37. See, e.g., Gladstone 1969, 184; Lascaratos 1999, 73; Rennie 2012, 30: binocular heterochromia.
} 
So, if we were to take the literary sources at face value, Alexander the Great was short and pale, with eyes of different colour and with a wry neck. ${ }^{38}$ The medical profession has paid special attention to diagnosing Alexander's neck posture.

\section{Medical explanations for the twisted neck}

Based primarily on a minute examination of the Azara herm in the Louvre - which he believed to be a copy of Lysippos' Alexander with the lance - the physician Amédée Dechambre in 1851 presented a paper on Alexander in which he proposed that the Macedonian suffered from orthopaedic torticollis (FIG. 6). ${ }^{39}$ Torticollis, which means twisted neck, may be congenital or acquired. It denotes a condition in which the sternocleidomastoid muscle is shortened on the involved side leading to an ipsilateral tilt and contralateral rotation of the face and chin. More plainly put, the head is laterally tilted towards the shoulder and the neck

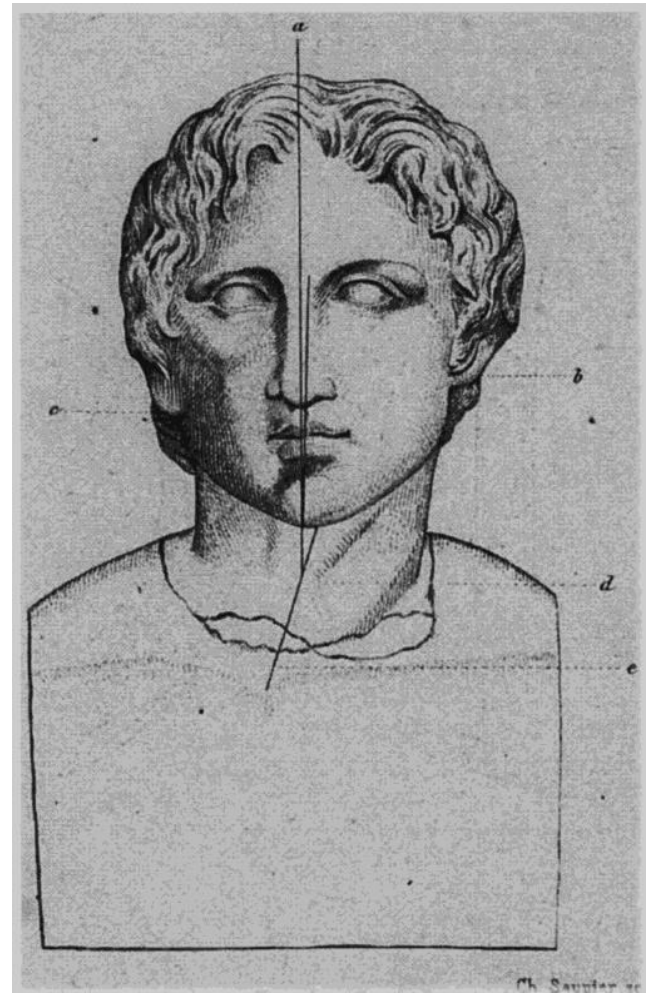

FIG. 6 - Azara Alexander. Second century AD. Paris, Louvre, MA 436 (after Dechambre Revue archéologique 1852, pl. 197). is twisted. While the neck tilts in one direction, the head and gaze tend towards the opposite direction. Due to the stiffness of the neck, the sufferer has problems moving his or her head. In addition to congenital muscular torticollis, there are non-muscular conditions such as neurological torticollis and ocular torticollis. ${ }^{40}$

Dechambre's interest in the medical condition of an ancient historical figure was in line with a related interest bestowed upon Greek mythological figures in effigy in the mid to late nineteenth century. Thus in 1886, the anatomist Wilhelm Henke diagnosed Venus de Milo with a deformed spine and believed she had a limp since her legs appeared to be of unequal length. ${ }^{41}$ This misconception was due to a wedge-shaped piece of marble then missing from her hip, and only later inserted. More apropos Alexander's physiognomy, Henke's colleague Christoph Hasse studied the asymmetry of Venus' face, noting that the right and left halves differed in width (this asymmetry, found in many ancient marbles, is probably due to the fact that the sculpture was not meant to be viewed strictly en face). Hasse compared the statue with human subjects and

\footnotetext{
38. It has also been speculated whether Alexander was left-handed: McManus 2006 and Small 2006 both reach the conclusion that he was not.

39. Dechambre 1851; Dechambre 1852-53, 422-34.

40. Karmel-Ross 1998.

41. Henke 1886.
} 
concluded that lateral asymmetry was normal for human figures whether in flesh or stone. ${ }^{42}$

Dechambre's torticollis diagnosis entered into archaeological publications and public awareness quite early on. In 1886 Alfred Emerson could therefore claim that 'every schoolboy knows' that Alexander's head was 'inclined slightly towards the left shoulder, a condition known as torti collis'. ${ }^{43}$ Not all archaeologists were convinced. In one of the first studies of Alexander's portraiture, Friedrich Koepp declared the idea totally unconvincing. ${ }^{44}$ All the same, repeated references to Alexander's suffering from torticollis appeared in medical publications in the first half of the twentieth century. ${ }^{45}$ Some physicians, however, dismissed the diagnosis. A portrait in London, thought to be from Alexandria, shows the young ruler with head turned slightly to the left giving it an energetic appearance (FIG. 7). ${ }^{46}$ With reference to this head, K.F. Hulbert stated that 'this is not a deformity: it is a pose'. ${ }^{47}$

In 1973, the historian Fr. Schachermeyr proposed that Alexander suffered from kyphosis, roundback or hunchback, acquired from an injury during his birth. ${ }^{48}$ While kyphosis may be accompanied by a tilt of the neck ( $c f$. the

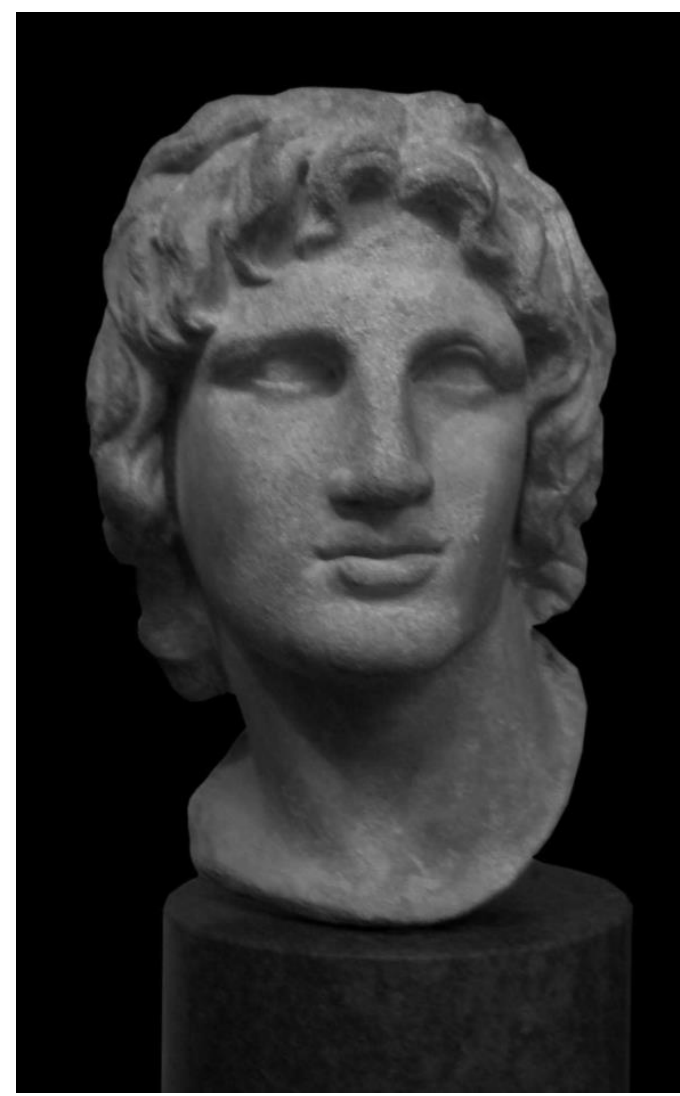

FIG. 7 - Alexander from Alexandria. Ca 250 BC. London, British Museum, BM 1857 (photo: author). actor Charles Laughton as the hunchback from Notre Dame), there seems to be no visual or written indication of Alexander having a hunch. At least the images that show him from the neck down follow an ideal male form in accordance with the Lysippic canon. ${ }^{49}$

In recent decades physicians have again turned their attention to Alexander the Great, now focusing on possible eye diseases. J. Laskaratos and A. Damanakis propose that Alexander had ocular torticollis or Acquired Brown's syndrome, an eye condition that leads to a tilt of the head in an upwards position or to one side. ${ }^{50}$ Their arguments are based on the ivory head

\footnotetext{
42. Hasse 1882; Hasse 1886; cf. Güntürkün 1991.

43. Emerson 1886, 411; Emerson 1887, 249.

44. Koepp 1892, 8-9.

45. E.g., Colonna 1927, 794; Little 1927, 12.

46. London, British Museum, BM 1857; Stewart 1993, 331, 424, fig. 124.

${ }^{47 .}$ Hulbert 1950, 50.

48. Schachermeyr 1973, 95.

49. See, e.g, the bronze statuette in the Louvre, MN 1576, from Egypt, Fouquet Alexander, known in various versions, Kiilerich 1988, fig. 6; Stewart 1993, 425.

${ }^{50 .}$ Lascaratos and Damanakis 1996a; Lascaratos and Damanakis 1996b.
} 


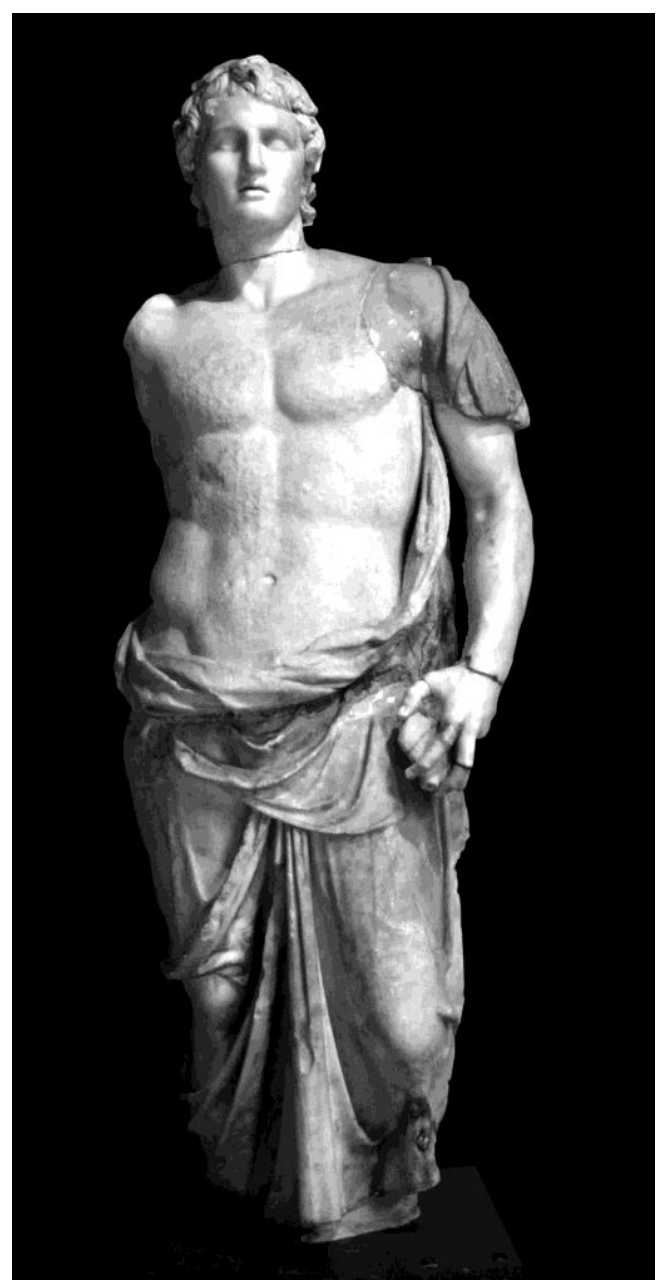

FIG. 8 - Alexander from Magnesia. Third century BC. Istanbul Archaeological Museum, inv.no. 709. from Tomb II at Vergina. Dismissing this diagnosis, J.F. Acheson and N. Nitsas, in a reply to Laskaratos and Damanakis, point out that the head tilt is present in most of the small ivory heads from Vergina. If the tilt was due to a medical condition, it would have been Familial Brown's syndrome rather than the acquired type. However, they find that the tilt is more likely a question of style. ${ }^{51}$ The ophthalmologist B. de Vries also dismisses the various medical diagnoses - kyphosis, congenital muscular torticollis, and two types of Brown's syndrome. He warns that it is almost impossible to diagnose an orthopaedic disease without clinical observation and examination and concludes that 'the abnormal head posture is due to the artistic style. ${ }^{52}$ In any event, the diagnosis has become part of the medical curriculum. Karen Karmel-Ross states that 'it is speculated that Alexander the Great suffered from muscular torticollis because he had a lifting of the neck with a slight bending to the left. ${ }^{53}$ Hutan Ashrafian proposes Alexander had a cervical scoliotic deformity (scoliosis is a spinal deformity closely related to torticollis), and that he died from the consequences of this congenital syndrome. Ashrafian further holds that 'descriptions and statues typically portray Alexander with a cervical neck deformity with the added possibility of ocular muscle deficits and facial asymmetry. ${ }^{, 54}$ Similarly, in a recent paper on congenital muscular torticollis, T.D.

Twee notes that 'one of the earliest written references to this deformity appeared in Plutarch's classic description of Alexander the Great. ${ }^{, 55}$ In an overview of spinal deformities, Elias Vasiliadis refers to the Macedonian king as suffering from scoliosis, presenting as evidence the statue of Alexander from Magnesia, which is claimed to display body asymmetry (FIG. 8). ${ }^{56}$

\footnotetext{
51. Acheson and Nitsas 1996.

52. De Vries 2005.

53. Karmel-Ross, 1998, 9.

54. Ashrafian 2004, 138. Williams \& Arnott 2004 suggest that the stone that struck Alexander in 329 and rendered him temporarily blind resulted in a carotid artery dissection which also had a bearing on his death. The proble ms of retrospective diagnosis are addressed by York and Steinberg 2004.

55. Twee 2006; also Marzoeki 2007, 260.

56. Vasiliadis, Grivas and Kaspiris 2009, with reference to the article of Ashrafian 2004 and the statue of Alexander from Magnesia, Istanbul Archaeological Museum, no. 709, on fig. 3; Stewart 1993, 334-36, fig. 133.
} 
Indeed, Alexander's torticollis (or scoliosis) has become a standard entry even in the most recent medical publications on the disease. We find statements such as 'Alexander the Great may have had torticollis, according to Plutarch', 57 'original written references to this deformity appeared in Plutarch's description ..., 58 and, most recently, 'the King of Macedonia ... is believed to have this deformity'. ${ }^{59}$

\section{The depiction of physical defects in ancient art}

Beginning with Dechambre, who based his diagnosis on the Azara herm, physicians have interpreted Alexander's looks in terms of a potential orthopaedic defect, especially torticollis, 'wry neck'. Yet a fundamental methodological question is whether it is at all possible to base a retrospective diagnosis on images. For members of the medical profession who use their skills on art historical material, the art historian Marc Gotlieb has coined the phrase 'doctor art history'. He points to a tendency to read into art works certain diagnostic traits with regard either to the artist or to the represented subject. Examples range from seeing kidneys in paintings of Michelangelo, who had a urologic problem, to diagnosing visual impairment amongst the impressionists. ${ }^{60}$

An instance of alleged physical deformity in antiquity is the onion-shaped head of Perikles, his so-called schinokephaly. For Perikles' cranial protuberance, the source again is Plutarch: 'his head was rather long and out of due proportion', furthermore the historian claims that Perikles' portraits wore helmets because 'the artists would not reproach him with deformity'. ${ }^{61}$ Since Plutarch finds it unlikely that artists should have shown Perikles' alleged deformity, it is equally unlikely that he should have assumed artists to have taken the opposite stand in the portrayal of Alexander. Thus, although Plutarch seems to infer that Alexander habitually held his head in an upward slant as represented in his official image, he does not appear to imply that this poise was due to a cervical defect. As for Perikles, discussing his helmeted portrait type in a lengthy article, Beth Cohen compares it to that of the Riace bronze $\mathrm{B}$ and convincingly concludes that the 'cranial deformity' is actually a technical device that served as a helmet support. It was structurally necessary and not physiologically descriptive. ${ }^{62}$

If we turn to Alexander's father, Philip II, an unmistakable feature of his physical appearance is the arrow wound in his right eye that he incurred, whilst still a young man, at the siege of Methoni in 355 BC. ${ }^{63}$ Was this rendered in his portraits? The official portraiture of Philip II remains elusive as hardly any representations can be identified with any degree of certainty. A bearded diademed head in Copenhagen has been tentatively accepted as a portrait of the mature Philip II, but the evidence is circumstantial as the sculpture, bought in Rome in 1910,

\footnotetext{
57. Beasley 2012, 763.

58. Mohan and Bhat 2012, 364.

59. Kansara, Mohan, Bhat and Bhat 2014, 28.

60. Gotlieb 2008, esp. 95-101.

61. Plutarch, Perikles 3.2.

62. Cohen 1991, esp. 481 and 484.

63. Bartsiokas 2000; Lascaratos, Lascaratos and Kalantzis 2004. For the written sources of the eye wound and the wounds in the collar bone and leg, see Riginos 1994.
} 


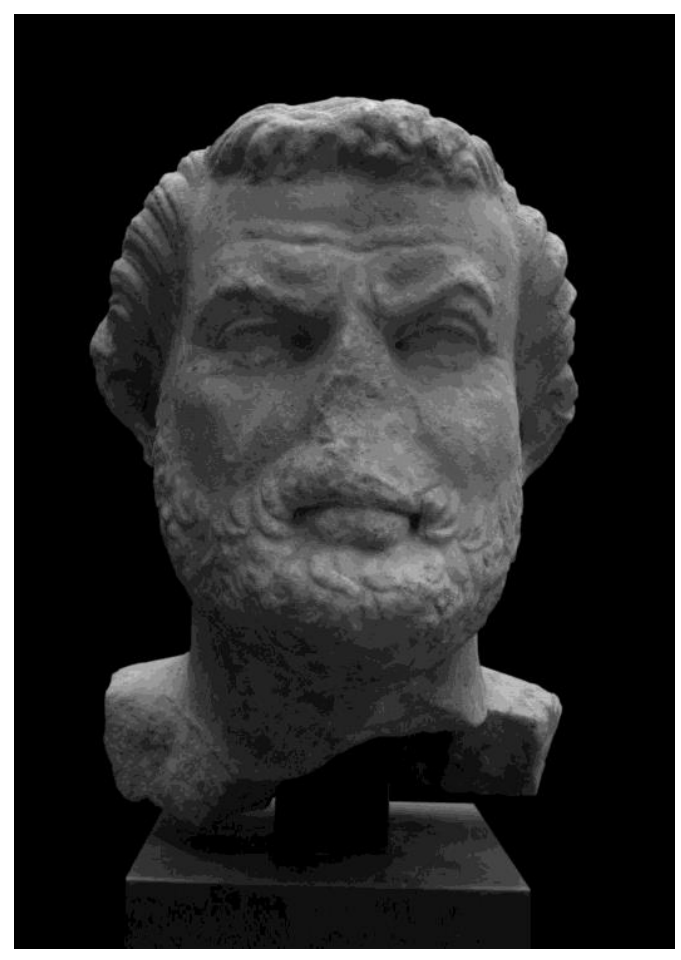

FIG. 9 - Philip II. Second century AD. Copenhagen, Ny Carlsberg Glyptotek, inv.no. 2466 (photo: author). has no secure provenance (FIG. 9). ${ }^{64}$ A small nick on the right eyebrow has been taken as a deliberate indication of a scar. ${ }^{65}$ The left eyebrow is lifted and an eye wound may be hinted at in the form of ocular asymmetry, but the portrait does not reveal any actual disfigurement of the right eye. The tiny bearded ivory head $(3.5 \mathrm{~cm})$ from Tomb II at Vergina, which has been associated with Philip II, appears to have a scar across the right eyebrow. While this may suggest a wound, it also exposes the trap of reading too much into an image. At any rate, whether given visual form or not, Philip's wound may be classified as a heroic wound, visual evidence of his daring and heroic action in battle. This is obviously altogether different from a congenital deformity like torticollis. Even battle wounds were not necessarily rendered in visual representations. For instance, Antigonos Monophthalmos, the One-eyed, who had lost an eye in battle, did not like to be depicted in such a way that this was shown. ${ }^{66}$

With regard to Alexander's presumed physical appearance - slight stature, pale skin and crooked neck - Andrew Stewart, one of the

foremost experts on the portraiture of Alexander, proposes that 'ancient Greek portraitists could sidestep some of these peculiarities and clever ones could turn the rest to decided advantage'. They could 'turn his crooked neck into a badge of heroic defiance'. And further about the neck: 'this was a personal quirk, it was not obtrusive, and Lysippos dealt with it tactfully. ${ }^{, 67}$ This was also tentatively suggested by H.P. L'Orange, who, although he seriously doubted that the bent neck was characteristic of the real Alexander, noted that if it were, then Lysippos had converted physical peculiarities into 'a new and expressive motif'. ${ }^{68}$ But the question remains, if Alexander did have a visible defect, would the artists have depicted it, or would they have left it out?

In antiquity physical defects were mainly represented in the guise of caricature, as in images of dwarfs, pygmies and other outsiders. The Hellenistic period saw an increasing interest

\footnotetext{
64. Copenhagen, Ny Carlsberg Glyptotek, inv.no. 2466; Yalouris 1980, 98, cat. 1; Johansen 1992, 60-61. Not Philip II: Nielsen 2007.

65. Prag and Neave, 1997, 79-80. For the proposed reconstruction of the king's head see, Prag 1990; Prag and Neave 1997, 63, fig. 6.

${ }^{66}$ Pliny NH 35.90; Lascaratos 1999, 74-5.

${ }^{67}$ Stewart 2003, 33-34; Stewart 1993, 76.

${ }^{68}$ L'Orange 1947, 131, n. 3.
} 
in character studies of, for instance, old fishermen with sagging skin and wrinkled old women clutching empty wine lagynoi ${ }^{69}$ Such studies may have served various purposes ranging from the ethnographical to the apotropaic, and should not be dismissed as mere genre. Still, in general, it seems that in the Greek world, 'beauty and wholeness were regarded as a mark of divine favour, whereas ugliness and deformity were interpreted as a sign of the opposite.' 70 Since physical defects were habitually seen as bad omens, it is rather unlikely that a potential physical defect should have been highlighted in ruler portraiture which was required to present the subject to his best advantage.

\section{Alexander's public image}

Neither the visual nor the textual evidence provides any definite clues to Alexander's physical appearance. Plutarch based his interpretation on statues, and the statues were designed to visualize desired ruler qualities and virtues, not to show physical peculiarities. In all likelihood, the public portraiture of Alexander, particularly as designed by Lysippos, bore but little resemblance to the 'real' Alexander whose physical appearance is quite uncertain. Since the mature, bearded looks of Philip II were unsuitable for the official image of young Alexander, a different image had to be fashioned. ${ }^{71}$ It can be demonstrated with a large degree of probability that this image was constructed from a number of standard features with positive connotations and that they were used to show his leonine and courageous nature. The lion's mane indicated courage and the moist eye signified a brave man. This was all according to the book, namely the pseudo-Aristotelean Physiognomonica. ${ }^{72}$

The literary sources that reflect this official image also use standard terms influenced by theories of physiognomics and theories of the humours (moist eyes, dry limbs). Plutarch mentions the neck together with the moist (hygrotes) eyes, a physiognomic feature of positive value, and stresses the king's leontodes, ('lion-likeness'). According to the physiognomist Polemo (ca 88-ca 145), the leonine man was of moderate stature, of fair complexion tinged with red and his eyes were moist and shining. ${ }^{73}$ This recalls in a general way the cliché-like descriptions of Alexander. But rather than negative traits, in physiognomical thinking moderate stature and fair complexion are to be interpreted in a positive manner.

In contrast to modern-day mass-media coverage of royalty, the majority of the inhabitants in the vast Hellenistic empire would never have been eye to eye with their ruler. Thus they would never have experienced in person what Alexander actually looked like. They knew him primarily from visual images ranging from the statues that were set up all over the empire, to coins that were even more profusely distributed. ${ }^{74}$ At all events, rather than verisimilitude and a realistic representation of physical appearance, it was important to present a con-

\footnotetext{
${ }^{69}$ Zanker 1989; Sande 1995.

${ }^{70}$ Garland 1995, 2.

${ }^{71}$ Hölscher 2009, 55, for the design of Alexander's image as that of a young hero.

${ }^{72}$ Guépin 1964; Kiilerich 1988, 51-66; Kiilerich 1993, 87-88.

${ }^{73}$ For Polemo, see Evans 1941; Evans 1950, 280; Swain 2007, 19-226. For the importance of the eye and vision, see Plantzos 1999-2000, who notes the emphasis on the eye in the Alexander mosaic, gems and coins.

${ }^{74}$ Philostratus mentions golden statues of Alexander near Taxila, in present Pakistan (Vit. Apoll. 2.24.; 2.42), and bronze tablets displaying the exploits of the Indian king Porus and Alexander wrought in orichalcus, silver and gold in a temple at Taxila (2.20); Stewart 1993,179-80, 400: T127.
} 
vincing image of the king's arête, his manliness and noble character. Therefore, no matter what defects and deformities Alexander may have suffered from, his images would not have been required to reveal them. How then can the exaggerated head posture of some of his representations be understood?

\section{Artistic explanations of the twisted neck}

Of the tilted heads, the posthumous marble found at Yannitsa, some $6 \mathrm{~km}$ from the royal capital Pella, is likely to derive from a local tradition. However, since bronze was the favoured material for male portrait-statues, there is little reason to believe that this marble, broken off at the neck, belonged to a freestanding statue (see FIG. 5a). It is most likely a fragment of a two- or multi-figural composition. ${ }^{75}$ It is therefore conceivable that some other fortuitously preserved tilted heads originally belonged in a narrative and dramatic context. In such narrative settings, the protagonist is unlikely to have been depicted en face. Due to the action - say a lion hunt or a battle scene - Alexander would have been represented in an ac-

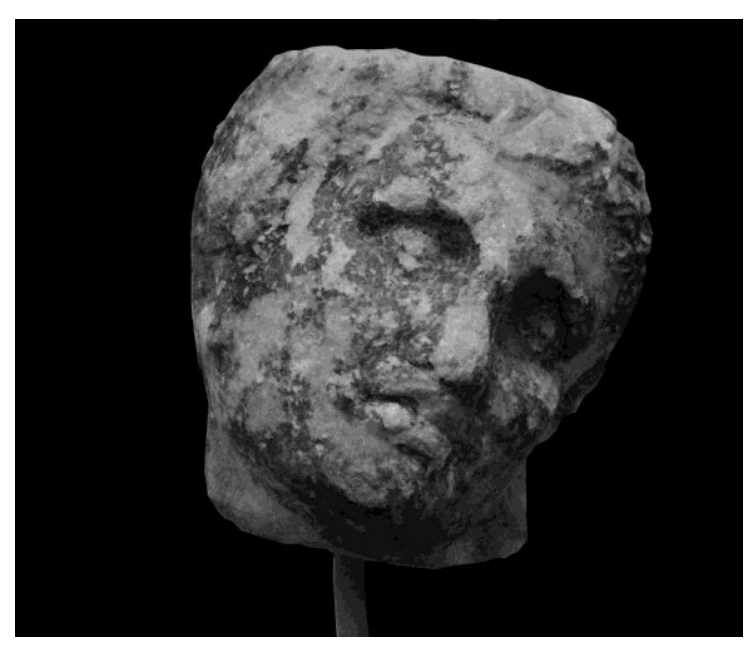

FIG. 10 - Head from the Temple of Athena Alea, Tegea. Ca 350 BC. Athens, National Archaeological Museum (photo: author). tive pose with head in three-quarter or full profile view, turned to the side or upwards in order to intimate action. A turn of the head, whether to the side or upwards, gives the figure a more dynamic appearance; but viewed out of context, as a fragment in a museum, the physiognomy will often appear somewhat disjointed. An example of this is the Alexandrian portrait in Copenhagen mentioned above (see FIG. 4). Alexander displays a dynamic turn, but there is nothing 'abnormal' in the posture. Moreover, when the sculpture is seen from below in a low-angle view, the figure appears more powerful. ${ }^{76}$

Sculptures from various contexts, such as the pediments of the Temple of Athena Alea at Tegea, ca 350 BC, show vigorously turned and tilted heads (FIG. 10). ${ }^{77}$ Because the pose in the pediment sculptures is conditioned by the dynamic narrative, it can be interpreted as a highly conscious and mannered attitude. The upturned head pose is characteristic also of some of the ivory heads from Tomb II at Vergina and from other Macedonian tombs. ${ }^{78}$ The bodies being lost, it is impossible to reconstruct the original compositions, but narratives of some sort can be imagined. Alexander's exaggerated head posture can therefore be understood in light of artistic trends in the

\footnotetext{
${ }^{75}$ For group compositions with figures in action, see, e.g., Calcani 1989; Calcani 1993; Moreno 1993.

${ }^{76}$ Kraft 1987.

${ }^{77}$ Athens, National Archaeological Museum and Tegea, Archaeological Museum; Stewart 1977.

${ }^{78}$ Andronikos 1988, figs. 76-86. Ivories from a tomb at Korinos, ca 325-300, Alfano 1995, 200-201.
} 
fourth century, as a pose adopted in order to visualize his 'drive' and dynamic personality. ${ }^{79}$ However, this feature could have a more specific iconographic origin.

\section{Alexander and Helios}

The public images of Alexander the Great adopted traits from several gods and heroes such as his role models Achilles and Herakles. ${ }^{80}$ This carefully contrived imagery could be varied according to the intended public. The numismatic evidence shows a range of possibilities: the king's head clad in Herakles' lion pelt, in a Dionysian elephant's scalp (exuvia), and most famously with the ram's horns of Amun. ${ }^{81}$ An Alexander-Pan association also existed, as presented in a large statuette of a naked youth at Pella: the head is that of Alexander while two small horns and a tail point to Pan. ${ }^{82}$ In some instances, it is uncertain whether Alexander lent his features to the divinity, or whether Alexander borrowed divine features and attributes. It has, for instance, been argued that Lysippos' statue of Zeus from Nemea, possibly with upturned head, derived this pose from Alexander's iconography. ${ }^{83}$ Another significant divine component was that of Helios. ${ }^{84}$ Since preserved images of Alexander/Helios are comparatively late, or difficult to date with precision, it is debated whether Alexander's iconography was influenced by that of Helios or whether it was the other way round. ${ }^{85}$

When Alexander conquered the Indus region in 326, he is said to have sacrificed to Helios as the God who had given him the lands of the East. ${ }^{86}$ Golden statues of Alexander were allegedly set up in the sanctuary of the Sun at Taxila, in present Pakistan. ${ }^{87}$ It was also claimed that the sun never shone on the lands he did not conquer. ${ }^{88}$ Some of Alexander's successors were likened to the sun, thus Demetrios of Phaleron was heliomorphos, Antigonos was 'son of the Sun' and Demetrios Poliorketes 'the sun among the stars'. ${ }^{89}$

Alexander conquered Egypt in 332. Since all pharaohs were perceived as son of Ra (son of the Sun) - for long identified with Amun-Ra - as the ruler of Egypt, Alexander was automatically associated with the Sun. A late Hellenistic alabaster statuette from Egypt (Brooklyn) with a curly mane of hair, head turn and upward gaze has seven holes for the rays of the Sun. There seems little doubt that it represents Alexander as Helios. ${ }^{90}$ Unfortunately it cannot be dated with precision. A chronological fix point for ruler/Sun association may however be

\footnotetext{
${ }^{79}$ L'Orange 1947, 19-27, emphasizes Alexander's heavenward gaze as a spiritual expression of his yearning (pothos); similarly Pollitt 1986, 29, sees the turn of the neck and the upward gaze as expressions of Alexander's aspiring personality.

${ }^{80}$ For instance, Tondriau 1949; Antela-Bernárdez 2007, discussing Achilles, Heracles and Dionysos.

${ }^{81}$ For the coins, see Price 1991. A solar symbolism of the elephant is noted by Turcan 1966, 466.

${ }^{82}$ Moreno 1995, cat. 106; Laubscher 1985.

${ }^{83}$ Lichtenberger 2013.

${ }^{84}$ L'Orange 1947, 33-37; Hoffmann 1963; Kiilerich 1993, 88-89; Schörner 2001; Trofimova 2012, esp. chap. VI, 103 23, discussing Alexander's influence on the imagery of Helios, Herakles, Dionysos and Achilles.

${ }^{85}$ Hoffmann 1963, 122: 'it is impossible to say for certain in every instance whether Alexander has been idealized as Helios, or whether Helios has been assimilated to the type established for Alexander'. L'Orange 1947, 33-37, implies that Alexander's image was influenced by that of Helios; in contrast, Hölscher 1976, 37; Stewart 1993, 180; Schörner 2001; Hölscher 2009, 71, find that Helios was influenced by Alexander.

${ }^{86}$ Diod. 17.89; Curt. 9.1.1.

${ }^{87}$ Philostr. Vit. Apoll. 2.24.; 2.4 .

${ }^{88}$ Plut. Mor. 330D.

${ }^{89}$ Epithets: L'Orange 1947, 35.

${ }^{90}$ Grimm 1998, 18-19, with colour photo.
} 
furnished by a small image of Ptolemy I Soter (323-305, and from 305-285 king of Egypt), with his head encircled by rays. As Günter Grimm states: Ptolemy took over the divine attributes of Alexander, including 'der Strahlenkranz des Helios'. ${ }^{91}$ Since the Macedonian Ptolemy ca 305/285 is represented in the guise of the sun, it is reasonable to assume that his great predecessor Alexander was conceived as 'Alexander-Helios' in the Egyptian realm. Alexander is depicted as Amun-Ra, the sun god with $\mathrm{hm}-\mathrm{hm}$ crown in a bronze bust of uncertain date, while on a monumental scale he stands as pharaoh next to Amun in a relief in the god's temple at Luxor. ${ }^{92}$

As far as the Greek realm is concerned, one extant image is eloquent: The Sun-god in his chariot is depicted on a metope from the Temple of Athena at Ilion (Troy), which was built around or shortly after $300 \mathrm{BC}$. With sturdy neck, upturned head, deep-set eyes, clouded brow and full upswept hair, Helios has unmistakable Alexander-like features. ${ }^{93}$ As in the duck-rabbit picture, the image may shift from 'Helios' to 'Alexander'; it can be taken as Helios in the guise of Alexander or Alexander in the guise of Helios, that is a crypto-portrait of the ruler. That Alexander here lent his features to Helios is in keeping with the fact that the king had promised to build a new temple at Ilion, a project realized by his successor Lysimachos (305-282)..$^{94}$

Lysippos was especially noted for the bronze statue of Helios in his chariot he made for the Rhodians, incidentally mentioned by Pliny right before he mentions Lysippos' many portraits of Alexander ('Nobilitatur Lysippus .. in primis vero quadriga cum Sole Rhodiorum. Fecit et Alexandrum Magnum multis operibus', NH 34.63). As for the date, historical circumstances render 331 as a likely post quem for Lysippos' Helios. ${ }^{95}$ This composition is recorded on the island's amphora stamps. As in the Ilion metope, the horses are shown in threequarter profile view, and Helios' dress is fluttering in the air to indicate his strong movement. It is difficult to make out details of Helios' head in the tiny image, but he appears to turn his head upwards in a near frontal view. ${ }^{96}$ Lysippos' pupil Chares from Rhodes was the creator of the famous bronze Colossus of Helios, one of the Seven Wonders of the ancient world. ${ }^{97}$ An over life-size marble head, recognizable as the patron god of the Rhodians from the holes for rays added in bronze, has been found on Rhodes (FIG. $11 \mathrm{a}, \mathrm{b}, \mathrm{c}$ ). ${ }^{98}$ Since this third- to second-century sculpture is not worked in the round and has a large hole in the back, it must have belonged to an architectural context. This context is generally believed to be the pediment of the temple of Helios. As at Ilion and as in Lysippos' lost composition, the Sun-god

\footnotetext{
${ }^{91}$ Grimm 1998, 63, fig. 62; 66. See, however, Bergmann 1998, who holds that rays were infrequent in Alexander's portraiture.

${ }_{92}$ Pfrommer 1999, fig. 31 and fig. 42; Winter 2005.

${ }^{93}$ Berlin, Staatliche Museen, Pergamonmuseum, inv. no. 9582; Goethert \& Schleif 1962; Holden 1964, 6-18; Jucker 1969; Kunze 1992, 190-91, no. 85; Moreno 1995, 184, no. 4.26.3.

${ }^{94}$ Strabo 13.1.26.

${ }^{95}$ See Moreno 2004 b, 468 (with references).

${ }^{96}$ Pliny, NH 34.63; Holden 1964, pl. IV, fig. 6 (Athens, Agora museum); Moreno 1995, 398-401.

${ }^{97}$ Pliny, NH 34.41; Higgins 1989; Hoepfner 2000.

${ }^{98}$ Rhodos, Archaeological Museum, no. E 49 (55 cm); Konstantinopoulos 1977, no. 144, p. 86-88, with fig. 12 on p. 85; Pollitt 1986, 55, fig. 48.
} 

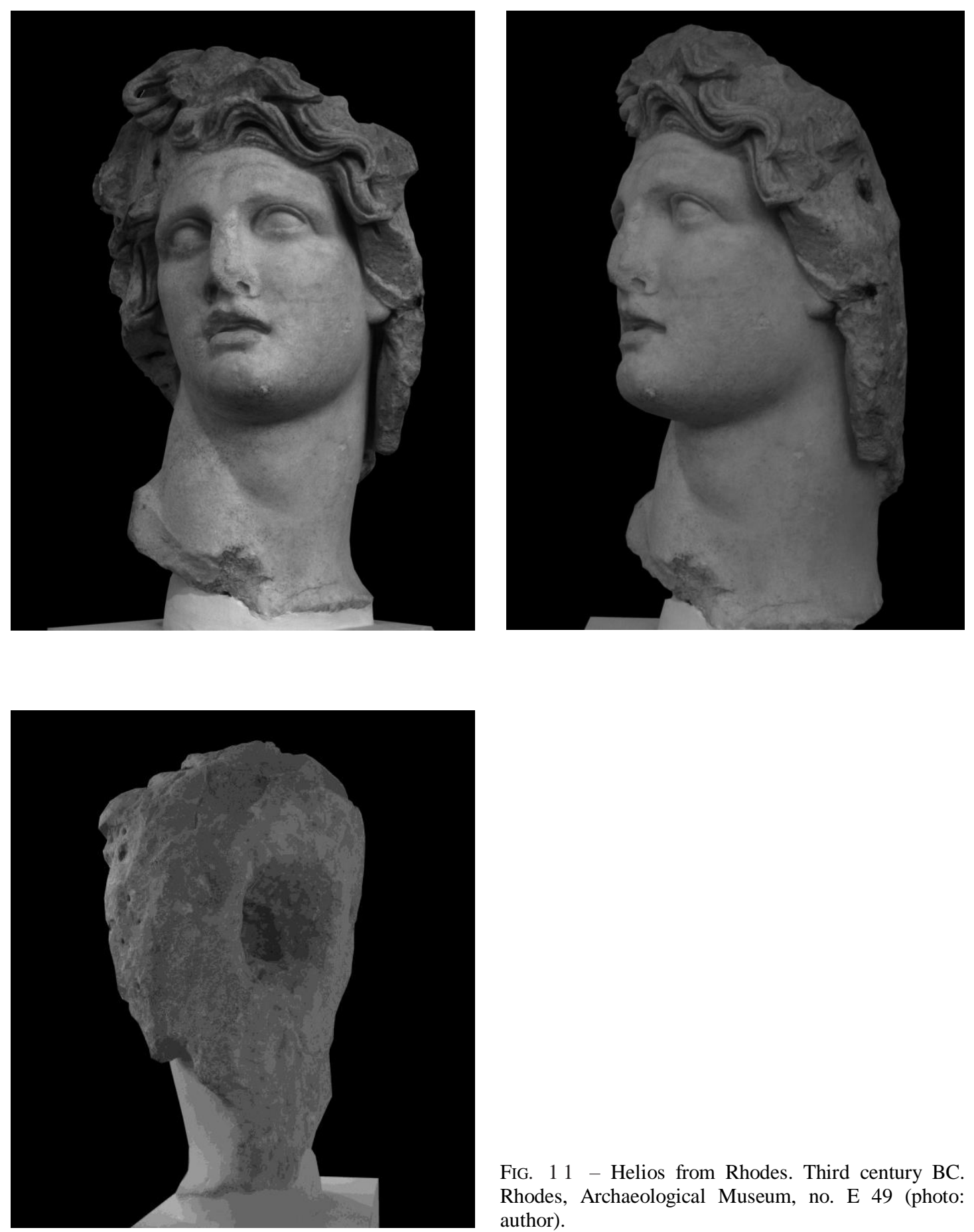

FIG. 11 - Helios from Rhodes. Third century BC. Rhodes, Archaeological Museum, no. E 49 (photo: author). 


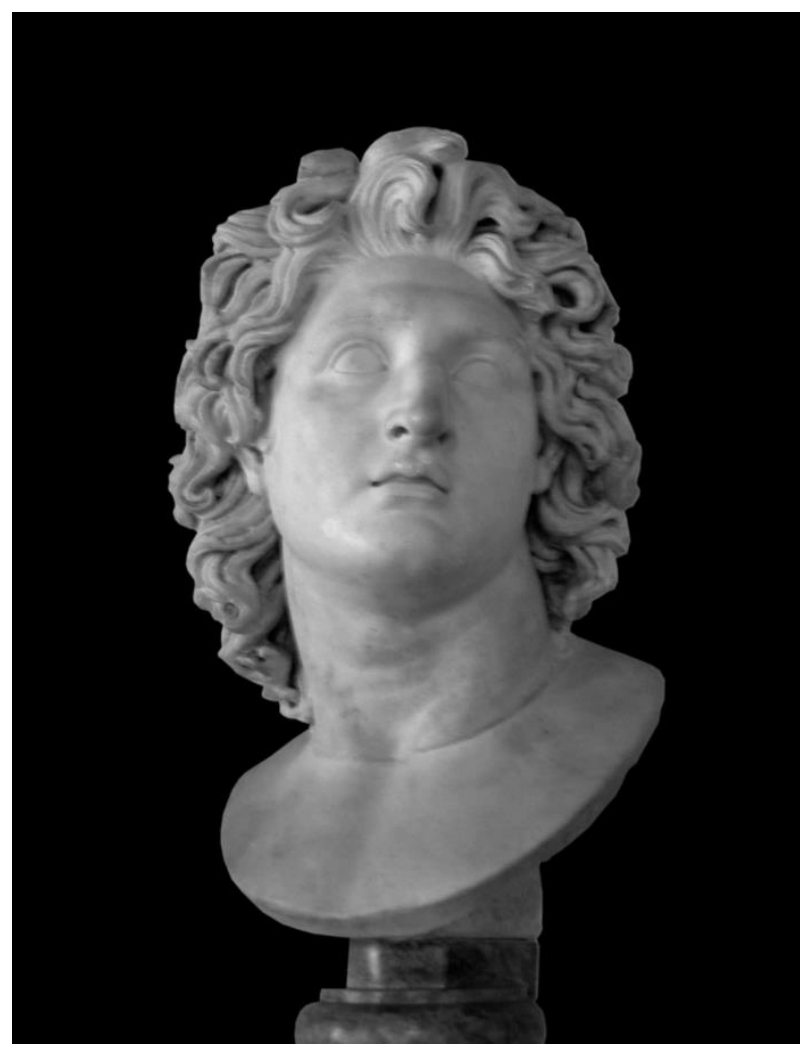

FIG. 12 - Alexander-Helios. Roman period. Rome, Museo Capitolino, inv.no. 732 (photo: author).

was presumably originally depicted in a quadriga. ${ }^{99}$ His head displays a marked tilt. The Sun rises in the east and moves across the sky. To show this movement, Helios' head is vigorously turned and so inevitably acquires a tilt. It is close at hand to see in the Helios marble a reflection of the two famous bronze Helioi, that of Chares and that of Lysippos. ${ }^{100}$ The question then is: did Lysippos' Helios borrow the neck pose from Alexander's image, or did the artist, when fashioning the image of the 'heavenward-gazing' Alexander, adopt the Sun-god's turn towards the sky? While current scholarship favours the notion of the ruler lending his features to the divinity, if the origin of the pose is Lysippic, the influence may have been reciprocal. At any event, the upward turn was well suited to express the drive and energy (dynamis) of the young ruler. ${ }^{101}$

The vigorous head posture became one of many potential ingredients in Alexander's portraiture. In later periods this trait was at times grossly exaggerated, just as the fullness of the hair could be blown out of proportion and romanticized, as in the Capitoline head (FIG. 12). Since many other rulers and their followers were subsequently depicted with tilted heads, the fashion apparently caught on. Emperor Augustus was sometimes represented with his head inclined, one example being the marble portrait from La Alcudia on Mallorca. ${ }^{102}$ Hadrian was also portrayed with a vigorous tilt, a portrait from his villa at Tivoli embodying the trend. In a different vein, Caracalla went for a strong head turn and imitated Alexander's trux frons, his cloudy brow. ${ }^{103}$ Constantine the Great adopted the heavenward gaze - without head turn - and became closely associated with the Sun. ${ }^{104}$

\footnotetext{
${ }^{99}$ For the excavation of the site of the Temple of Helios, see Lojacono 1936, 245-287.

${ }^{100}$ Pollitt 1986, 55: 'The head's turbulent shock of hair and turn of the neck are reminiscent of the Lysippan Alexander portraits'.

${ }^{101}$ Stewart 1993, 334, refers to 'the dynamis of the sun-king'.

${ }^{102}$ For Augustus' portraits, see, e.g., Vierneisel \& Zanker 1979. Alcudia head: Zanker 1990, 43, fig. 33.

${ }^{103}$ Castritius 1988; Hannestad 1993, with Hadrian, 65, fig. 5; Kühnen 2008.

${ }^{104}$ See, e.g., Wallraff 2001; Bergmann 2006.
} 


\section{Conclusion}

Based on the visual and written sources, physicians from the mid-nineteenth century till today have diagnosed Alexander the Great with congenital muscular torticollis or ocular torticollis. It has further been suggested by archaeologists that the creators of Alexander's official portrait could have reinterpreted the alleged cervical neck deformity by giving it a positive turn or twist. I have argued here that in view of the negative attitude to physical disabilities in antiquity, and in view of the symbolic rather than realistic nature of Alexander's public image, it is unlikely that artists would have depicted a ruler who was meant to be perceived as physically strong and able-bodied as in any way physically impaired. It seems equally unlikely that the image-conscious Roman emperors Augustus and Hadrian would have been depicted with their heads tilted in the manner of Alexander, had the presentational mode been based on a medical condition. Thus although in certain portraits Alexander's 'heroic turn', when seen out of context, may appear not dissimilar to the medical condition torticollis, the most plausible explanation is that the twisted turn is a carefully contrived pose. If the Rhodian marble head of Helios reflects Lysippos' work, it is reasonable to propose that Lysippos used this twisted pose both for his Helios and for his heavenward gazing Alexander. At all events, it was not because of neck problems that the great Alexander vigorously turned his head and raised his gaze in effigy: it was an outward sign of the young ruler's energetic and dynamic temperament.

Bente Kiilerich

University of Bergen

Dept of Linguistic, Literary and Aesthetic Studies

$\mathrm{Pb} .7805, \mathrm{~N}-5020$ Bergen

Bente.Kiilerich@uib.no 


\section{BIBLIOGRAPHY}

Acheson, J.F., Nitsas, N. 1996: "Ocular Torticollis in the Macedonians" (Letter), The Lancet, vol. 347, 1126.

Alfano, C. (ed.) 1995: Alessandro Magno - storia e mito (exhib. Cat.), Rome.

Andreae, B. 1977: Das Alexandermosaik aus Pompeji, Recklinghausen, $3^{\text {rd }}$ edit.

Andronikos, M. 1988: Vergina. The Royal Tombs, Athens.

Antela-Bernárdez, B. 2007: "Alejandro Magno o la demostración de la divinidad", Faventia 29/1, 89-103.

Antikas, T.G., Wynn-Antikas, L.K. 2015: "New Finds from the Cremains in Tomb II at Aegae point to Philip II and a Scythian Princess", International Journal of Osteoarcheology (published online 25. August 2015), DOI: 10.1002/oa.2459.

Ashrafian, H. 2004: "The Death of Alexander the Great - a spinal Twist of Fate", Journal of the History of the Neurosciences vol. 13, no. 2, 138-142.

Bartsiokas, A. 2000: "The Eye Injury of King Philip II and the skeletal Evidence from the Royal Tomb II at Vergina", Science 53, 2, 511-514.

Bartsiokas, A. et al. 2015: "The Lameness of King Philip II and Royal Tomb I at Vergina, Macedonia", Proceedings of the National Academy of Sciences of the United States of America June 2015 www.pnas.org/cgi/doi/10.1073/pnas. 1510906112.

Beasley, S.W. 2012: "Torticollis", in Coran, A.G. et al., (eds.), Pediatric Surgery, Philadelphia, 763-770.

Bergmann, M. 1998: Die Strahlen der Herrscher. Theomorphes Herrscherbild und politische Symbolik im Hellenismus und in der römischen Kaiserzeit, Mainz.

Bergmann, M. 2006: "Konstantin und der Sonnengott. Die Aussagen der Bilderzeugnisse", in Demandt, A., Engemann, J. (eds.), Konstantin der Grosse. Geschichte. Archäologie. Rezeption, Trier, 143-161.

Bieber, M. 1964: Alexander the Great in Greek and Roman Art, Chicago.

Brown, T.S. 1949: "Callisthenes and Alexander", AJPh 70, 225-248.

Cagiano de Azevedo, M. 1967: "Una nuova personificazione di Alessandro Magno", Rassegna di Studi del Civico Museo Archeologico di Milano, 5-16.

Calcani, G. 1989: Cavalieri di bronzo. La torma di Alessandro Magno opera di Lisippo, Rome.

Calcani, G. 1993: "L'immagine di Alessandro Magno nel gruppo equestre del Granico", in Carlsen, J. et al. (eds.), Alexander the Great. Reality and Myth (ARID suppl. XX), Rome, 29-39.

Castritius, H. 1988: “Caracalla, Augustus und Alexander?", in Will, W. (ed.), Zu Alexander der Grossen, Amsterdam, 879-894.

Chilidis, K. 2012: The Construction of Knowledge in Archaeology - the Case of "Philip's Tomb" at Vergina in Northern Greece, Oslo.
Cohen, A. 1997: The Alexander Mosaic, Cambridge.

Cohen, B. 1991: "Perikles' Portrait and the Riace Bronzes. New Evidence for 'Schinokephaly”, Hesperia 60, 465-502.

Colonna, P.C. 1927: "Congenital Torticollis", Virginia Medical Monthly 53, 794.

Cook, B. 2001: "Plutarch's Use of LEGETAI: narrative Description and Sources in Alexander", Greek, Roman and Byzantine Studies 42, 329-360.

Dahmen, K. 2007: The Legend of Alexander the Great on Greek and Roman Coins, London.

Dechambre, A. 1851: "Caracterès de la figure d'Alexandre, éclairés par la médecine", Gazette médicale de Paris 18 , 717-720, 745-748.

Dechambre, A. 1852-53: "Caracterès des figure d'Alexandre le Grand et de Zénon le Stoïcien, éclairés par la médecine", $R A$ 9, 2, 422-440.

De Vries, B. 2005: "Alexander the Great's abnormal Head Posture due to Brown's Syndrome?", Transactions of the $29^{\text {th }}$ European Strabismological Association Meeting, 211212.

Drews, R. 1962: "Diodorus and his Sources", AJPh 83, $383-$ 392.

Ehrhardt, W. 2008: "Das Alexandermosaik oder: Wie autentisch muss eine historische Darstellung sein?", $\operatorname{MDAI}(R)$ 114, 215-269.

Emerson, A. 1886-1887: "The Portraiture of Alexander the Great: a terracotta Head in Munich (I)", AJA 2, 408-413; (II) AJA 3, 243-260.

Enoch Powell, J. 1939: “The Sources of Plutarch's Alexander", JHS 59, 229-240.

Evans, E.C. 1941: "The Study of Physiognomy in the second Century AD”, TransactAmPhilosSoc 72, 96-108.

Evans, E.C. 1950: "Physiognomics in the Roman Empire", Classical Journal 45, 277-282.

Fernández Gomez, F. n.d.: Archaeology Museum of Seville. Official Guide, Seville.

Garland, R. 1995: The Eye of the Beholder: Deformity and Disability in the Graeco-Roman World, New York.

Gebauer, K. 1938-39: "Alexanderbildnis und Alexandertypus”, $M D A I(A)$ 63-64, 1-106.

Gladstone, R.M. 1969: "Development and Significance of Heterochromia of the Iris", Neurology 21, 2, 184-192.

Goethert, F., Schleif, H. 1962: Der Athena-Tempel von Ilion, Berlin.

Gotlieb, M. 2008: "Our monstrous Double: the Dream of Research in 'Outsider Art History"', in Holly, M.A., Smith, M. (eds.), What is Research in the Visual Arts? Obsession, Archive, Encounter, Yale, 85-102.

Grimm, G. 1998: Alexandria. Die erste Königsstadt der hellenistischen Welt, Mainz.

Guépin, P. 1964: "Leonine Brows and the Shadow of Pyrgoteles", BABesch 39, 129-39. 
Güntürkün, O. 1991: "The Venus de Milo and the Dawn of facial Asymmetry Research", Brain and Cognition 16, 147150 .

Hannestad, N. 1993: "Imitatio Alexandri in Roman Art", in Carlsen, J. et al. (eds.), Alexander the Great. Reality and Myth (ARID suppl. XX) Rome, 61-69.

Hartle, R.W. 1982: "The Search for Alexander's Portrait", in Adams, W.L., Borza, E.N. (eds.), Philip II, Alexander the Great, and the Macedonian Heritage, Washington D.C., 153-176.

Hasse, C. 1882: Die Venus von Milo, Jena.

Hasse, C. 1886: "Über Gesichtsasymetrien", Archiv für Anatomie und Physiologie, 119-125.

Henke, W. 1886: "Glossen zur Venus von Milo", Zeitschrift für bildende Kunst 21, 194-199, 222-227.

Higgins, R. 1989: "The Colossus of Rhodes", in Clayton, P., Price, M. (eds.), The Seven Wonders of the Ancient World, London, 124-137.

Hölscher, T. 1971: Ideal und Wirklichkeit in den Bildnissen Alexanders des Grossen (Abh. Heidelberg. Akad. Wiss. Phil.-Hist. Kl. 2), Heidelberg.

Hölscher, T. 2009: Herrschaft und Lebensalter. Alexander der Grosse: Politisches Image und anthropologisches Modell (Jacob Burckhardt-Gespräche auf Castelen 22), Basel.

Hoepfner, W. 2000: "Der Koloss von Rhodos", AA, 129-153.

Hoffmann, H. 1963: "Helios", Journal of the American Research Center in Egypt 2, 117-123.

Holden, B.M. 1964: The Metopes of the Temple of Athena at Ilion, Northampton, Mass.

Hulbert, K.F. 1950: "Congenital Torticollis", The Journal of Bone and Joint Surgery 32B, no.1, 50-59.

Johansen, F. 1992: Greek Portraits. Ny Carlsberg Glyptotek, Copenhagen.

Johnson, F.P. 1927: Lysippos, New York.

Jucker, H. 1969: "Zur Heliosmetope aus Ilion”, AA, 248-256.

Kansara, A.A., Mohan, M., Bhat, K., Bhat, S. 2014: "Congenital muscular Torticollis - Case Series and Review of Literature", Journal of Dental and Medical Sciences 13, 4, 2832.

Karmel-Ross, K. (ed.) 1998: Torticollis: Differential Diagnosis, Assessment and Treatment, Surgical Mana-gement and Bracing, London.

Kiilerich, B. 1988: "Physiognomics and the Iconography of Alexander", SO 63, 51-66.

Kiilerich, B. 1993: "The public Image of Alexander the Great", in Carlsen, J. et al. (eds.), Alexander the Great. Reality and Myth (ARID suppl. XX), 85-92.

Kiilerich, B. 2015: Visual Dynamics. Reflections on Late Antique Images, Bergen (https://uib.academia.edu/-Bente Kiilerich).

Koepp, F. 1892: Über das Bildnis Alexanders des Grossen, 52. Program zum Winckelmannsfeste, Berlin.

Konstantinopoulos, G. 1977: Musées de Rhodos, I: Musée archéologique, Athens.

Kraft, R.N. 1987: "The Influence of Camera Angle on Comprehension and Retention of pictorial Events", Memory and Cognition 15, 291-307.

Kühnen, A. 2008: Die Imitatio Alexandri in der römischen Politik (1.Jh.v.Chr. - 3.Jh.n.Chr.), Münster.

Kunze, M. (ed.) 1992: Die Antikensammlung im Pergamonmuseum und in Charlottenburg, Berlin.
Lascaratos, J. 1999: “"Eyes' on the Thrones", Survey of Ophthalmology 44, 1, 73-78.

Lascaratos, J., Damanakis, A. 1996a: "Ocular Torticollis: a new Explanation for the abnormal Head-posture of Alexander the Great", The Lancet, vol. 347, 521-523.

Lascaratos, J., Damanakis, A. 1996b: "Torticollis in ancient Macedonians" (Letter), The Lancet, vol. 348, 346.

Lascaratos, J., Lascaratos, G., Kalantzis, G. 2004: "The ophthalmic Wound of Philip II of Macedon (360-336 BCE)", Survey of Ophthalmology 49, 2, 256-261.

Laubscher, H.P. 1985: "Hellenistische Herrscher und Pan", $\operatorname{MDAI}(A)$ 100, 333-353.

Leimbach, R. 1979: "Plutarch über das Aussehen Alexanders des Grossen", $A A$ 94, 213-220.

Lichtenberger, A. 2013: "Der Zeus Nemeios des Lysipp und Alexander der Grosse", in Kalaitzoglou, G., Lüdorf, G (eds.), Petasos. Festschrift für Hans Lohmann, Paderborn, 179-192.

Little, E.M. 1927: "Orthopaedics before Strohmeyer", The Robert Jones Birthday Volume, Oxford, 12.

Lojacono, P. 1936: "La Chiesa conventuale di S. Giovanni dei Cavalieri in Rodi", Clara Rhodos VIII:4, Bergamo, 245287.

L'Orange, H.P. 1947: Apotheosis in Ancient Portraiture, Oslo.

McManus, C. 2006: "The modern Myth of the Lefthandedness of Alexander the Great", Laterality 11, 6, 566572.

Marzoeki, F.D. 2007: "Congenital muscular Torticollis with Shortening of right sternocleidomastoid Muscle", Folia Medica Indonesiana 43, 4, 260-264

Mohan, M., Bhat, S. e.a. 2012: "Congenital muscular Torticollis - Case Report and an effective Treatment Plan", Journal of Maxillofacial and Oral Surgery 11, 3, 364-367.

Moreno, P. 1973: Testimonianze per la teoria artistica di Lisippo, Rome.

Moreno, P. 1993: "L'immagine di Alessandro Magno nell'opera di Lisippo e di altri artisti contemporanei", in Carlsen, J. et al. (eds.), Alexander the Great. Reality and Myth (ARID suppl. XX), 101-136.

Moreno, P. (ed.) 1995: Lisippo. L'arte e la fortuna, Milan.

Moreno, P. 2000: Apelle. La Battaglia di Alessandro, Milan.

Moreno, P. 2004a: Alessandro Magno. Immagini come storia, Rome.

Moreno, P. 2004b: "Lysippos (I)", in Vollkommer, R. (ed.), Künstlerlexikon der Antike, Munich, 463-475.

Müller, S. 2014: "Lysippos, Apelles und Alexander. Zur Interikonizität eines Epigramms auf ein lysippisches Alexanderporträt”, www.uni.giessen.de/.../lysippos-apelles-undAlexander 1-26.

Musgrave, J. et al. 2010: "The Occupants of Tomb II at Vergina. Why Arrhidaios and Eurydice must be excluded", International Journal of Medical Sciences 7, 6, 1-15.

Nielsen, A.M. 2007: “A reworked Antisthenes”, BABesch 82, 191-200.

Pandermalis, D. (ed.) 2004: Alexander the Great. Treasures from an Epic Era of Hellenism, New York, 15-45.

Pfrommer, M. 1999: Alexandria im Schatten der Pyramiden, Mainz. 
Plantzos, D. 1999-2000: “Alexander's Gaze: Peripatetic Concepts of Vision and their Influence on Hellenistic royal Portraiture", Archaiognosia 10, 65-86.

Pollitt, J.J. 1986: Art in the Hellenistic Age, Cambridge.

Prag, A.J.N.W 1990: "Reconstructing King Philip II: the 'nice' Version", AJA 94, 237-247.

Prag, J., Neave, R. 1997: Making Faces. Using Forensic and Archaeological Evidence, London.

Price, M. 1991: The Coinage in the Name of Alexander the Great and Philip Arrhidaeus, London.

Radt, W. 1981: “Der 'Alexanderkopf' in Istanbul: Ein Kopf aus dem grossen Fries des Pergamon-Altars", AA, 583-596.

Rennie, I.G. 2012: "Don't make my blue Eyes brown: Heterochromia and other Abnormalities of the Iris", Eye 26, 2950.

Ridgway, B.S. 1990: Hellenistic Sculpture I, Madison.

Riginos, A. Swift 1994: "The Wounding of Philip II of Macedon: Fact and Fabrication", JHS 114, 103-119.

Sande, S. 1995: "An old Hag and her Sisters", SO 70, 30-53.

Schachermeyr, F. 1973: Alexander der Grosse. Das Problem seiner Persönlichkeit und seines Wirken (Österreichischen Akademie der Wissenschaften) Vienna.

Schörner, G. 2001: "Helios und Alexander. Zum Einfluss der Herrscherikonographie auf das Götterbild", AA, 59-68.

Schwarzenberg, E. 1969: "From the Alessandro Morente to the Alexandre Richelieu. The Portraiture of Alexander the Great in Seventeenth-Century Italy and France", JWCI 32, 398-405.

Schwarzenberg, E. 1976: "The Portraiture of Alexander", in Alexandre le Grand (Entretiens sur l'Antiquité Classique 22), Geneva, 223-278.

Small, J.P. 2006: "Was Alexander the Great left-handed?", Laterality 11, 6, 562-565.

Smith, R.R.R. 1990: "Late Roman Philosopher Portraits from Aphrodisias", JRS 80, 127-155.

Stähli, A. 'Der sogenannte Kopf Fortnum: Zwar Alexander, aber eine Fälschung', $A A$ 2000, 341-53.

Stewart, A. 1977: Skopas of Paros, Park Ridge.

Stewart, A. 1993: Faces of Power: Alexander's Image and Hellenistic Politics, Berkeley.

Stewart, A. 2003: "Alexander the Great in Greek and Roman Art”, in Roisman, J. (ed.), Brill's Companion to Alexander, Leiden, 31-66.

Swain, S. (ed.) 2007: Seeing the Face, Seeing the Soul. Polemon's Physiognomy from Classical Antiquity to Medieval Islam, Oxford.

Tondriau, J. 1949: “Alexandre le Grand assimilé à différentes divinités”, Revue Philologique 23, 41-52.
Tonsing, E.F. 2002: "From Prince to Demi-god: the Formation and Evolution of Alexander's Portrait", in Asgeirsson, J.M., van Deusen, N. (eds.), Alexander's Revenge, Reykjavik, 85-109.

Trofimova, A. 2002: Imitatio Alexandri in the Hellenistic Art, Rome.

Turcan, R. 1966: Les sarcophages romains à représentations dionysiaques, Paris.

Twee, T.D. 2006: "Congenital muscular Torticollis: current Concepts and Review of Treatment", Current Opinion in Pediatrics 18, 26-29.

Vasiliadis, E.S, Grivas, Th.B., Kaspiris, A. 2009: "Historical Overview of spinal Deformity in ancient Greece", Scoliosis 4,6 .

Vierneisel, K., Zanker, P. 1979: Die Bildnisse des Augustus: Herrscherbild und Politik im kaiserlichen Rom, Munich.

von den Hoff, R., 2009: "Alexanderporträts und Bildnisse frühhellenistischer Herrscher', in Hansen, S. et al. (eds.), Alexander der Grosse und die Öffnung der Welt, Asiens Kulturen im Wandel, Regensburg, 47-53.

von den Hoff, R. 2014: "Neues im 'Alexanderland': Ein frühhellenistisches Bildnis Alexanders des Grossen”, Göttinger Forum für Altertumswissenschaft 17, 209-245.

Wallraff, M. 2001: "Constantine's Devotion to the Sun after 324", Studia patristica 34, 256-269.

Wardman, A.E. 1967: "Description of personal Appearance in Plutarch and Suetonius: the Use of Statues as Evidence", Classical Quarterly n.s. 17, 2, 414-420.

Williams A.N., Arnott, R. 2004: "A Stone in the Siege of Cyropolis and the Death of Alexander the Great", Journal Historical Neuroscience 13, 2, 130-137.

Winter, E. 2005: "Alexander der Grosse als Pharao in ägyptischen Tempeln”, in Beck, H., Bol P.C., Bückling, M. (eds.), Ägypten. Griechenland. Rom. Abwehr und Berührung, Frankfurt, 201-215.

Wünsche, R. 2006: Ein Bildnis von Alexander dem Grossen, Munich.

Yalouris, N. (ed.) 1980: The Search for Alexander: An Exhibition, Boston.

York, G.K., Steinberg, D.A. 2004: "The Diseases of Alexander the Great", Journal of Historical Neuroscience 13, 2, 153-156.

Zanker, P. 1989: Die Trunkene Alte. Das Lachen der Verhöhnten, Frankfurt.

Zanker, P. 1990: The Power of Images in the Age of Augustus, Ann Arbor. 